\title{
A Study of EFL Students' Interpretations of Cultural Aspects in Foreign Language Learning
}

Osiris Hernández Castro, Yolanda Samacá Bohórquez

\begin{abstract}
This article explores the relevance of implementing the cultural aspects of both foreign and own countries as a paramount issue in the teaching of a target language. This small scale research project was developed as a component of the seminar on Bilinguism offered by Universidad Distrital in Bogotá as part of its Master's program in Applied Linguistics to the Teaching of English. The authors of this research collected data to find out and compare how university students from Tunja and Bogotá -two major Colombian cities- assess the incorporation of cultural aspects of the foreign country into the teaching of the foreign language. Thus, the guiding question of this research is: How do EFL students interpret cultural aspects embedded in foreign language learning?
\end{abstract}

Key Words: Culture, Assumptions, Behavioral Patterns, Bilingualism, Identity, Tolerance, Prejudice, Discrimination, Misinterpretation.

\section{Resumen}

Este artículo explora la relevancia de implementar los aspectos culturales de un país como parte fundamental de la enseñanza de una lengua extranjera. Este proyecto de investigación a pequeña escala se llevó a cabo como parte del seminario de Bilingüismo ofrecido por la Universidad Distrital de Bogotá en su programa de Maestría en Lingüística Aplicada a la enseñanza del Inglés como lengua extranjera. Las autoras de la investigación tomaron muestras en dos instituciones públicas de educación superior en Tunja y Bogotá para comparar las apreciaciones de los dos grupos de estudiantes universitarios en cuanto a los aspectos culturales como parte de la enseñanza de una lengua extranjera. La pregunta que guía la investigación es: Cómo interpretan los estudiantes de Inglés como lengua extranjera, los aspectos culturales inmersos en el aprendizaje de dicho idioma?

Palabras Claves: Cultura, Deducciones, Patrones de Comportamiento, Bilingüismo, Identidad, Tolerancia, Prejuicios, Discriminación, Interpretación Errónea.

\footnotetext{
* Received: 15-02-06 / Accepted: 18-07-06
} 


\section{Introduction}

Many understand culture as a compound of values and beliefs shared by a community, granting its members a sense of belonging and own identity. When we teach a foreign language, we should keep in mind that each culture behaves, thinks, communicates, perceives reality, and reacts to it in a particular way. It is our duty as language instructors to create a sense of cross-cultural awareness, cultural diversity and communication across cultures among our students. This will raise their understanding of how culture can influence their learning successfully. Culture can also influence students' personal relationships, social behavior, ability to deal with conflicts and sensibility to other cultures both at school and outside the classroom. The way we as teachers may approach this sensitive issue will not only help our students while they are at school, but also prepare them to become active members of the multicultural society we live in.

Most of our students will sooner or later be part of the working force of our society. Many of them will work abroad, and will have to adapt to the culture of the host country. Modern organizations possess multinational workforces operating globally. This globalization and the increasing internationalization have brought new cultural challenges to the business field. To interact successfully with people from different cultures greatly depends on our own capacity to understand not only our own culture but the culture of others. People who face new environments through trial and error may go through unnecessary hassles or fail to succeed in important business transactions.

When we are members of a school team or a work team with mixed ethnicities, backgrounds and genders, we are likely to be more creative than homogeneous groups may be. This creativity is greatly determined by the exposure to different cultures which makes us more knowledgeable, tolerant and respectful of ideological differences. The contact with other cultures will widen our scope and make us more receptive to changes and different views of the world; thus, we also become more creative. All these appreciations may seem to be far away from our students' near future, but the truth is that these facts are here to stay and it is our duty to prepare our students for them. For the time being, we should concentrate on setting the bases for what is to come. To promote socio-cultural awareness seems to us a good way to start.

The purpose of this article is to share with language teachers, novice researchers and language students not only the relevance of teaching the foreign 
culture as part of the language component, but to value students' appreciations, points of view, ideas and suggestions to improve our teaching practice.

\section{Literature Review}

The culture and foreign language learning constructs that guided this mini-scale research project are based upon the concerns noted in the preceding section. We will start by defining what culture is and what it implies, to highlight at a later stage how some cultural aspects might help students become more tolerant towards foreign cultures and more willing to acknowledge cultural differences.

\section{Culture and Foreign Language Learning}

There are different assumptions about culture, and we often assume that culture is only seen as a social aspect. There is a need to become aware of what culture means for education and what teachers are doing in our classrooms in order to integrate this concept as part of the modern language curriculum.

From a social perspective, Kroeber and Kluckhohn (1952) define culture as "the explicit and implicit patterns of behaviors, symbols and ideas that constitute the distinctive achievements of human groups" (cited in Díaz $\mathcal{E}$ Weed, 1995, p.195). Similarly, for Tylor (in Pearson, 1974, as cited by Díaz $\varepsilon$ Weed, 1995) culture is "that complex whole which includes knowledge, belief, art, morals, law, custom, and any other capabilities acquired by humans as members of society" (p.193). Nonetheless, Seelye (1976) argues that culture emerges as a broad concept embracing all aspects of human life, but the point is to try to find out why certain aspects, including behaviors take place.

If we take Seelye's idea, we may interpret that our social and cultural identities seem to be alike, but indeed they are not. The former, according to Hamers E Blanc (1995), "exists within the same society and helps the individual to define himself in relation to the roles and the social groups in that society" (p.117), and the latter emphasizes that "one can only become aware of one's cultural identity to the extent that one becomes cognizant of the existence of other cultures in or outside one's own society" (p. 117). Therefore, cultural identity is part of, but not the same as, social identity. These authors also 
assert that "the integration of the complex configuration that is culture into the individual's personality constitutes his cultural identity" (p.116).

Some researchers such as Hinojosa (2000), in a study about the relationship between culture, foreign language teaching, cultural stereotyping and attitudes in work on intercultural communication, assert that "in foreign language learning, knowledge of linguistic structures alone is not enough; we also have to understand the way of life of a foreign culture and the individuals living it" (p. 112).

From our personal point of view culture is all around us. Culture is what we are, the way we feel, think and behave. Culture is the legacy we received from our ancestors. It comprises a series of aspects such as music, traditions, folklore, customs and language that make us unique and give us a seal of identity. Culture can vary within the same country, the same community, and even the same family, as it modifies itself according to the different conditions it is exposed to. Our position as English teachers is that when people learn a foreign language, they should learn about the foreign culture as well, but not at the expense of their own cultural identity. Hinojosa (2000) suggests that "As teachers we can help our learners to raise cultural awareness by providing students with as much valid and accurate information about their own and foreign language as possible" (p.68). When we talk about a foreign language, we refer to "a language acquired by a person in addition to his/her mother tongue" (Cook, 1993, p.5). Similarly, Richards (1996) defines second language acquisition as "the processes by which people develop proficiency in a second or foreign language" (p. 325).

However, we teachers need to be aware that teaching or learning a foreign language implies more than knowing grammatical rules in order to communicate with others. In relation to foreign language learning, Cook (1993) asserts that language is at the center of human life; it is one of the most important ways people use to communicate. It is at this point, where we are to comprehend what culture in relation to a foreign language is all about: to help the student dig into a culture and to understand why people act or behave as they do.

Therefore language as a key component of culture becomes a relevant feature of the individual's social and cultural identity, which has to be studied in relation to the individual, and as Hamers E Blanc (1995) declare "unlike other components of culture, language interacts with it in specific ways: language is 
a transmitter of culture, furthermore, it is the main tool for the internalization of culture by the individual" (p. 116).

\section{When should Culture be Taught?}

As teachers, we sometimes give others the responsibility to teach culture, or we feel insecure and confused with regards to the cultural aspects we should teach in a foreign language course. So, we prefer to organize our classes in relation to linguistic matters and omit the teaching of culture because we do not have time to do it, or we believe that students will be exposed to it later on or simply because many of us do not possess enough knowledge about the cultures that speak the language we teach. In view of this, Seelye (1976) considers that language and culture can be brought together in different ways, by making language teaching interdisciplinary, by immersing the foreign language teacher and students in strategies to be used in and out of classes, by developing among students a positive attitude toward teachers' activities in foreign language programs. Therefore, culture needs to be an essential part of our curriculum, in classes at school or at a university level and in everyday situations with our students. Finally, it is worth highlighting that learning about a culture goes beyond studying a list of facts about history, music, arts or geography. Culture should include those aspects of life that concern people the most. As Seelye (1976) argues, an understanding of the way of life of foreign people is important to survive in a world of conflicting value systems, where the boundaries that formerly isolated and protected man from alien ideas have been eroded by advances in technology of communication or struck down by the angry clamor of the downtrodden in their search for a better life (p.12)

\section{The Project}

\section{Context of the Study}

This mini scale research project was developed in the seminar on Bilingualism and Bilingual Education in Latin America, conducted by Doctor Anne Marie de Mejia and offered by the Masters Program in Applied Linguistics at Universidad Distrital in Bogotá in 2005. During the reflective discussions held in our classes, we were motivated to conceptualize, interpret and analyze both our misunderstandings in relation to bilingual education in our country and our teaching and learning practices in foreign language classrooms. After working 
on EFL students' perceptions about bilingualism for our first poster presentation, we decided to continue working with their interpretations of cultural aspects embedded in foreign language learning. This is because our students were never exposed to immersion programs and their reality is that they are learning English as a foreign language in two state universities in Tunja and Bogotá.

This small-scale project attempted to identify students' understanding of culture in relation to foreign language learning and to describe their interpretations of cultural aspects involved in the learning process.

\section{Setting}

The contexts in which the study took place were two public institutions of higher education: UPTC (Universidad Pedagógica y Tecnológica de Colombia) located in Tunja- the capital city of Boyacá, a Colombian province with a long-standing rural and industrial tradition- and ILUD (Language Institute, Universidad Distrital) in Bogotá, the Colombian capital city. One of the main goals of the School of Languages at UPTC is to provide students with a holistic education, facilitating them to achieve a high degree of communicative competence in English and participate competitively in national and international contexts. The School of Languages fulfills this goal by teaching English as a foreign language to students enrolled in the Modern Language Teaching Progam (Licenciatura en Idiomas Modernos). The School also offers the Foreign Language Teaching Program (Licienciatura en Lenguas Extranjeras) and English for Academic Purposes to those students who are pursuing other majors in other schools at the same university.

In turn, the ILUD mission is "to provide an academic environment for the Capital District (i.e; Bogotá), where students can reach their human potential and contribute to their familiar and social environment". It was created in 2001 where initially four teachers would teach English, and the institute gathered 400 students. Four years later it now has 35 teachers, teaching English, German, French and Italian, and more than 2000 students.

\section{Participants}

\section{The Students}

One class of 16 students in Tunja, and another one of 15 intermediate students in Bogotá participated in this small-research project. In Tunja, most of the 
student were females; their ages ranged from 18 to 20 years old. They attended the course "Communicative Project VI" five hours a week. Most students had studied at public schools in Tunja, others came from towns nearby this city. This class was developed based upon mini-projects on British culture. In Bogotá, most students were young professionals. They were committed to the learning of English and clearly enjoyed the opportunity to become proficient in this language as part of their desire to join a multinational company and become citizens of the world someday in the near future. For this small-scale project, we asked two volunteers from each context to participate.

\section{The Researchers}

During the semester when we developed this mini-scale exploratory project, we were fourth semester students in the Masters program in Applied Linguistics to TEFL at Universidad Distrital in Bogotá. Both of us, novice researchers with previous teaching experience in public and private schools and universities in our country and abroad, were really interested in developing a project in two different settings with EFL adult students. Our main concerns were, on the one hand, to see the effects of including in the curriculum cultural aspects of the foreign language, and on the other, to get to know the ideas, understandings and perceptions that our students could have towards the topic.

\section{Data Collection and Analysis}

Students were invited to participate in this exploratory study as part of their regular classes. They agreed to take part in the project and we obtained their permission to use the data. As a very important aspect in doing research, the protection of their identities was guaranteed. In order to gather information for this small scale project, we collected data for about three weeks, using two instruments: The first one was a questionnaire where students were asked to report on their perceptions and interpretations about culture in foreign language learning. We decided to implement questionnaires because we needed them to elicit information about their interpretations of cultural aspects embedded in foreign language learning. We wanted to know their feelings, thoughts and understanding of the matter concerned. In words of Seliger $\&$ Shohamy. (1990), "questionnaires are used mostly to collect data on phenomena which are not easily observed, such as attitudes, motivation, and self- concepts" (p. 172). 
(See Appendix 1). As it is advisable to have another instrument to validate the data analysis, we used students' essays in order to have our students expand on their perceptions and to know their position in relation to culture in foreign language learning (See Appendix 2).This brief report of our research was written after the questionnaires were analyzed because, as we wanted our participants to elaborate on their interpretations, prompts based on their answers to the questionnaire were needed. The research question we wanted to work on was: How do EFL students interpret cultural aspects embedded in foreign language learning?

We carefully read and analyzed together student's answers to the questionnaire and their essays in order to identify their understanding of culture. Then we established which ideas described student's interpretations of cultural aspects. As this is a grounded data analysis, some issues in common emerged from the data.

\section{Findings}

Based upon the data analysis, we identified two basic issues in common: "culture: need or obligation?" and "cultural aspects". When reading students' responses about culture, we found that they considered these issues necessary and relevant in the teaching or learning of a foreign language.

\section{Culture: Need or obligation?}

This commonality is defined as the way EFL students see culture and its role in foreign language learning. They see culture as "the traditions and customs of different countries - the way people live" (sic, questionnaire, 9 November 2005), and as "one of the most important aspects that conform a country. Talking about culture is not only talking about theater or literature, but also about history, life styles, costumes or language of the country" (sic, essay, 9 November 2005). They also express that "as a languages student, during my career I've realized the importance of knowing the culture in order to improve the acquisition of a foreign language" (sic, 28 November 2005), and that "culture is always important in a country development and we as students of language, we must not learn a foreign language without to know the culture of that foreign language, in this case the British culture" (sic, essay, 28 November 2005). In short, they see culture as history, as knowledge about the world, 
as understanding, as identity. In the following excerpt one of the students underlines that "language is one of the most important facts that conform the culture. So, both facts complement each other, and the learning of one, implies the learning of the other. Culture becomes a way to learn the expressions that can't be translated and the different vocabulary which doesn't exist in the own culture" (sic, questionnaire, 9 November 2005).

Another view of culture is in relation to language or the other way around, language as part of culture. One of our students affirms that "It is evident that every country has its own culture, and its own way to show and keep it. This fact is held most of the time by language. Each country has a history and this history was told during so many years in an oral way; then, people began to write in order to maintain the traditions, myths and costumes generation by generation. So, it is an example that shows the presence of language in a culture and how culture is kept through language" (sic, essay, 28 November 2005).

\section{Cultural Aspects}

This commonality exemplifies what our students consider are some of the cultural aspects involved in learning a foreign language. We wanted to know students' interpretations of those aspects. Then, when students were asked about any cultural aspect taught to them in any of their English classes, they said that " there was no any relation between culture and language taught me at school, but through these five semesters all my English teachers made me keep in mind the importance of this relation..." (sic, questionnaire, 9 November 2005). Another student mentioned "the multicultural festivals in Great Britain, the National Day, how is held Christmas in Great Britain, etc" (sic, questionnaire, 9 November 2005). Afterwards, in their essays they wrote "in this post-modern period in which here is an abundance of thought, social facts and open-minded people, it is necessary to know a little bit about everything, because we are going to be encouraged to face all those facts as in service teachers. But it would be ambitious to pretend to know the whole culture of the country which we are learning the language, even if we haven't had the possibility to live there, but far as I'm able to judge, there are some relevant aspects that could help us to know culture and language. I'm talking about history, literature and music, the three ways in which each country shows the world its identity" (sic, essay, 28 November 2005). Another student thought that "in order to interact with people from different culture is necessary to 
know what is their language, in this case English, to know which are the main cities, the history, the principle celebrations like the National Day, Queen's Day, Christmas, etc." (sic, essay, 28 November 2005). In brief, all participants agreed on a social perspective of culture, such as multicultural festivals, the national day, Christmas, traditions, music, history and literature. If we compare once again these answers with those stated by Hinojosa (2000), we can point out that our participants still think of culture from a social perspective, or what Yli-Renko (1993, as cited by Hinojosa, 2000) calls Behaviorist theory, that "is not interested in the phenomenon itself, and it does not explain why a certain phenomenon exits or originates from" (p.114). Consequently, upon gathering these ideas, we can declare that foreign language learning consists of the teaching and learning of observable behaviors (as Hinojosa claims in his study)-i.e., issues such as the ones our participants listed in their responses to questionnaires and essays.

To sum up, the information found in these patterns highlights the importance culture plays in students foreign language classes and implicitly what we are teaching. Up to this point, we have presented two main patterns that we came across in this small scale project: "Culture: Need or Obligation?" and "Cultural Aspects". Now we will present our conclusions and pedagogical implications.

\section{Conclusions and Pedagogical Implications}

It is hard to imagine that we live in a problem-free world, and that, when different cultures get together, misunderstandings and confrontations would not arise, far from it. The problem of misunderstanding has many different sources: 1 - We live in a world where the word 'tolerance' is trendy. Everybody uses it but hardly anybody practices it. 2- Another source of the problem is misinterpretation: I either misinterpret what other people say, or they misinterpret what I say. This fact alone creates tension and anger. 3- We may add to these facts ignorance from both sides. Ignorance about the others' culture, beliefs and customs, and on their part, ignorance about one's culture, the way one feels or acts, which is part of ones cultural baggage. 4- We can add to this another common occurrence, fear- fear of the unknown, of anything that looks or sounds different, of being threatened by something one is not familiar with.

We believe that we should start in our classrooms a campaign towards tolerance, patience, understanding and willingness. We need to start raising awareness among our students of what is happening in the world. 
Cross-cultural communication and cross-cultural awareness are not new ideas. Luckily, nowadays people are starting to talk about these issues, this is the first step to reach understanding. We also believe that the key to effective cross-cultural understanding is knowledge, reflection, patience and willingness to change. It is everybody's responsibility to promote understanding, before the problem of misunderstanding gets out of hand causing the snow-ball effect, and degenerating into chaos.

Nieto, (2002) states that "Socio-cultural and socio-political perspectives are first based on the assumption that social relationships and political realities are at the heart of teaching and learning." (p. 91). It is there, in the classroom, where students shape their conceptions or misconceptions of the world. It happens especially when students start their puberty that the problem acquires gigantic dimensions. It is the moment when adolescents need peer-reassurance. Teenagers prefer to confront their families rather than their friends. It is at this point where strong social and racial prejudices start. These prejudices can be against color, language, race, social status, physical appearance, power etc. If there is no stop to this, the problem may develop into frustration and anger, to be transformed at a later stage into xenophobia, causing in some cases catastrophic consequences.

Prejudices and discrimination, as Nieto(2002) states "are not just personality traits or psychological phenomena. They are also manifestations of economic, political and social power." (p.79). Teachers should respect students' identities. Kohl (1994) suggests that "Student's failure to learn is not always caused by their lack of intelligence, motivation or self esteem". He maintains that "To agree to learn from a stranger, who does not respect our integrity, causes a major loss of self." (p.85). Because understanding is based upon the principle of mutual respect, we learn from each other, as long as we are willing to respect each others' beliefs and ideology.

Teachers do not have the answers to all these problems. The problems not only concern teachers but society in general. As this is a social issue, a team of professionals such as language teachers, educationalists, translators, psychologists, speech therapists, statisticians should deal with it with the same goal in mind: The solution of problems in educational settings.

Teachers can also help by creating and promoting awareness in the classrooms by being tolerant and respectful of different cultural identities. 
To use them to enrich their classes, to make the unknown known. To familiarize students with different cultures, discuss them and develop a critical understanding. This fact alone would be a gigantic step forward towards crosscultural awareness.

\section{References}

Cook, V. (1993) Second Language Learning and Language Teaching. Great Britain: Edward Arnold.

Díaz-Rico., \& Weed (1995). The nature of culture and cultures in contact. IN The Crosscultural Language, and Academic Development Handbook. Allyn \& Bacon.

Hamers, J. \& Blanc, M. (1995). Social psychological aspects of bilinguality: culture and identity. In Bilinguality \& Bilinguialism (p. 115-134) Cambridge: Cambridge University press.

Seelye, H. (1976). Teaching Culture. Skokie: National Textbook Co.

Seliger \& Shohamy (1990). Research design: qualitative and descriptive research. In Second Language Research Methods. (P. 1113-134, 172). Oxford: Oxford University Press.

Hinojosa, J. (2000) Culture and English Language Teaching: An intercultural approach. Cuadernos de Bilingüismo. (1), 107- 141

Kohl, H(1994). "I won't learn from you" and other thoughts on creative maladjustment. New York: The New York Press.

Nieto, S. (2002) Language, Culture and Teaching: Critical Perspectives for a new Century. New Jersey: Lawrence Erlbaum Associates, publishers.

Richards, J. (1996) Pedagogic Gramar and Second Language Acquisition. Cambridge: Cambridge University Press. 


\section{THE AUTHORS}

Osiris Hernández Castro is a Master in Applied Linguistics candidate at Universidad Distrital. She also holds an Undergraduate degree in Pedagogy and modern languages from Universidad Pedagogica Nacional, and a Specialization in English methodology. She is currently working as a full time teacher at Universidad Surcolombiana. Her research interests include bilingualism, critical pedagogy, critical reading and literature.

E-mail: omitche@usco.edu.co

Yolanda Samacá Bohórquez is a Master in Applied linguistics candidate at Universidad Distrital. She also holds an undergraduate degree in Pedagogy of writing processes. She is currently working at Universidad Pedagógica y Tecnológica de Colombia, School of Languages. Her research interests include bilingualism, teacher education development and literacy processes. E-mail: yolandasamaca@yahoo.com 


\section{Appendix 1 MASTER OF ARTS IN APPLIED LINGUISITCS TO THE TEFL SEMINAR ON BILINGUALISM AND BILINGUAL EDUCATION}

\section{QUESTIONNAIRE}

Dear student: The objective of this questionnaire is to know your interpretations of cultural aspects embedded in the process of learning English as a foreign language. Thank you for your cooperation.

1. What do you understand by culture?

2. What are the benefits (if any) of learning about a foreign culture?

3. Do you think that when you learn a foreign language you should learn the culture of the country?

Yes, Why?

No, Why?

4. Mention an instance of any cultural aspect ( traditions, multicultural festivals, theater, film, music, literature, financial aspects, so on ...) taught to you in any of your English classes. 
5. Do you think that understanding the English culture will help you learn the language or about the language? Explain

Thanks once again.

Student's name Date

E-mail:

\section{Appendix 2}

PROMPTS FOR THE ESSAYS

1. To interact successfully with people from different cultures depends greatly on our own capacity to understand not only our culture, but the culture of others. Do you agree or disagree? Explain.

2. Should the teaching/learning of a foreign culture be a necessary part of foreign language learning? Why or why not?

3. Write about the relevance or lack of it of teaching and learning cultural aspects in an English class?

4. Which cultural aspects would you like to learn or teach in your English classes and why? 